\title{
Characterization of Persian lime production (Citrus $\times$ latifolia; Tanaka ex Q. Jiménez)
}

\author{
Franco-Valderrama, Ana M. ${ }^{{ }^{*}}$; Caamal-Cauich, Ignacio ${ }^{1}$; Pat-Fernández, Verna G. ${ }^{1}$; \\ Pérez-Soto, Francisco ${ }^{1}$ \\ ${ }^{1}$ Universidad Autónoma Chapingo, Km 38.5. Carretera México-Texcoco. Chapingo, México. G.P. 56230. \\ * Correspondence: mareducacion2020@gmail.com
}

Citation: Franco-Valderrama, A. M., Caamal-Cauich, I., Pat-Fernández, V. G., \& Pérez-Soto, F. (2021). Characterization of Persian lime production (Citrus $\times$ latifolia; Tanaka ex Q. Jiménez). Agro Productividad. https:// doi.org/10.32854/agrop.v14il 1.1883

Editor in Chief: Dr. Jorge Cadena Iñiguez

Received: April 21, 2021. Accepted: October 29, 2021. Published on-line: November 26, 2021.

This work is licensed under a Creative Commons Attribution-NonCommercial 4.0 International license.

\begin{abstract}
Objective: To characterize the production system of Persian lime (Citrus $\times$ latifolia; Tanaka ex Q.Jiménez) in Martínez de la Torre, Veracruz, Mexico.

Design/Methodology/Approach: A semi-structured survey was applied with 50 Persian lime producers, through a directed sample. For this study a logistic regression was conducted: logit model, through measurement of the binary or dummy dependent variable, where the dependent variable takes values of " 0 and 1 ".

Results: Lime producers are mostly men with an average age of 54 years, the type of property is ejido and they have been producing lime from 15 to 30 years, the knowledge used for the production are rainy periods and soil fertility. Most use intolerant rootstock. Regarding the econometric result, variables with higher significance were obtained that are related to the dependent variable.

Study Limitations/Implications: It offers elements for the production of Persian lime.

Conclusions: Finally, there is low participation of women in agricultural tasks. When it comes to the application of fertilizers, pruning and an adequate use of fertilization influence the production yield.
\end{abstract}

Keywords: Production, Agriculture, Logit Model.

\section{INTRODUGTION}

Agricultural activities tend to be destined to the production of foods and to obtaining vegetables, fruits, leafy vegetables and cereals. Agriculture implies the transformation of the environment to satisfy the needs of man (Vivero \& Álvarez, 2020). "Most poor people in the world live in rural zones. Agriculture is a source of livelihood for 86 percent of the people who live in rural areas" (Organización de las Naciones Unidas para la Alimentación y la Agricultura (FAO), 2020). According to estimations by FAO (2020), agriculture provides employment to around 1,300 million smallholders and landless workers throughout the world. Nine out of ten farming operations in the world are managed by families and close to $80 \%$ of foods in the world are produced by family farms that are operated and nearly all depend on family workforce.

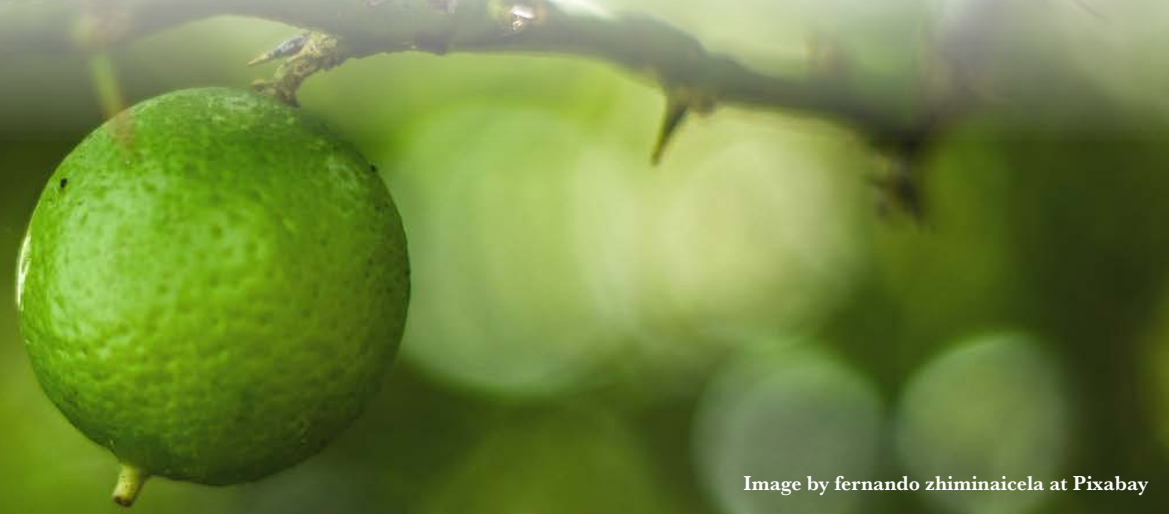


Small-scale farmers and family farmers have economic links with the rural sector, so they promote employment to a large degree, especially in developing countries where agriculture still concentrates the majority of the workforce (FAO, 2020). Concerning the data obtained by the Agriculture and Livestock National Survey (INEGI, 2020), for 2019 it reports that $17 \%$ of the positions of day laborers are occupied by women and $83 \%$ by men; from 100 producers, 17 are women responsible for the management and decision making in agriculture and livestock production units.

Regarding agriculture in Veracruz, this state has a solid agrifood production. Agriculture in Veracruz contributes $50.6 \%$ of the agrifood production of the state, followed by livestock production which contributes $47 \%$, and lastly the fishing sector that contribtues $2.4 \%$. It is the second state with greatest contribution to the national total (Agroproductores, 2020). The district Martínez de la Torre is known as the citrus capital; it is the district with most citrus activity. Table 1 shows that by 2019, Persian lime production occupies the first place with a surface of 15,584 harvested hectares, followed by the cultivation of orange with 9,571 hectares of harvested surface, and grapefruit occupies the third place with 2,280 hectares.

\section{Physiological characteristics of Persian lime (Gitrus latifolia)}

Persian lime is a tree that is planted with the use of the technique called pattern graft; that is, an active branch or shoot which is grafted in a pattern for its production. The pattern is a citrus variety resistant to root diseases and with the capacity to improve nutrient absorption (Agroproductores, 2020). The pattern selection will be done with the conditions of the producing agricultural zone and with the advice of an expert in the area. Some patterns used to graft Persian lime are: alemow (Citrus macrophylla), bitter orange (Citrus aurantium), volkamer lime (Citrus volkameriana), among others (Agroproductores, 2020).

\section{MATERIALS AND METHODS}

Description of the study site

The state of Veracruz is found in central-eastern Mexico, on the Gulf of Mexico coast. It has 212 municipalities and according to the most recent Population and Housing Census from INEGI (2020), the state is leader in sugarcane, orange, pineapple and maize grain production. Products such as lime and coffee are recognized globally due to their quality

Table 1. Main citrus fruits in Martínez de la Torre.

\begin{tabular}{l|r|r|c|c|c|c}
\hline Gultivation & Sown & Harvested & $\begin{array}{c}\text { Production } \\
\text { volume (ton) }\end{array}$ & $\begin{array}{c}\text { Yield } \\
\text { (ton) }\end{array}$ & Price & $\begin{array}{c}\text { Production value } \\
\text { (thousands of pesos) }\end{array}$ \\
\hline Lemon & $15,584.00$ & $15,534.00$ & $229,221.60$ & 14.76 & $6,560.29$ & $1,503,761,018.82$ \\
\hline Orange & $9,571.00$ & $9,530.00$ & $121,939.50$ & 12.80 & $2,369.04$ & $288,879,580.80$ \\
\hline Grapefruit & $2,280.00$ & $2,275.00$ & $102,375.00$ & 45.00 & $3,329.74$ & $340,882,132.50$ \\
\hline Tangerine & 128.00 & 125.00 & $2,485.00$ & 19.88 & $3,000.00$ & $7,455,000.00$ \\
\hline
\end{tabular}

Source: Prepared by authors with information from the database (SIAP, 2020). 
and exported to more than 20 countries in the world. The most important municipalities of the state in agricultural production are Tres Valles, Playa Vicente, Álamo Temapache, Coatepec and Isla, and in terms of Persian lime production they are Atzalán, Cotaxtla, Cuitláhuac, Carrillo Puerto, Martínez de la Torre, Misantla, San Rafael, Tlapacoyan and Papatlan (INEGI, 2020).

The municipality of Martínez de la Torre is located in the northern zone of the state, on coordinates $20^{\circ} 04^{\prime}$ latitude North and $97^{\circ} 04^{\prime}$ longitude West, at an altitude of 151 meters above sea level. It borders north with Tecolutla, Papantla and San Rafael, east with Nautla and Misantla, south with Atzalan, Misantla and Tlapacoyan, and west with Papantla and the state of Puebla; it has a surface of $815.13 \mathrm{Km}^{2}$ and occupies $1.07 \%$ of the territory in Veracruz; it is located at an approximate distance of $101 \mathrm{Km}$ from Xalapa, capital of the state of Veracruz (H. Ayuntamiento de Martínez de la Torre, 2019). Regarding the study zone, it is represented by conventional producers of Persian lime, from the municipality of Martínez de la Torre in the state of Veracruz.

\section{Research techniques}

Fifty (50) semi-structured surveys were conducted through sampling directed toward different producers of Persian lime. In the first section of the survey, the sociodemographic characteristics of the producers were identified, and in the second section the economic characteristics that were used for the econometric model.

For the data analysis obtained, the IBM Statistical Package for Social Science (SPSS) Version 25 software was used, where statistical tests and the logit regression model were carried out. Relative frequency and absolute frequency were used for descriptive statistics.

\section{Econometric model}

For this study, a modelling process was conducted through the logistic regression econometric model: logit model, by measuring the dependent variable productivity, which is binary or dummy; that is, it is only characterized with two values, " 0 " for producers that have low productivity which are under the average of the yield obtained in the study zone and " 1 " for producers that obtain yields higher than the mean. The independent variables were: surface (ha), fertilizer 20-10-20, complex fertilizer and pruning.

\section{The Logit model was considered a binary response model}

$$
P\left(Y=1 \mid X_{1}, X_{2},, X k\right)=G\left(\beta_{0}+\beta_{1} X_{1}+\beta_{2} X_{2}+,,,+\beta_{k} X_{k}\right) \quad \text { Equation (1) }
$$

To avoid the problems of the linear probability model, they are specified as $y=G(X \beta)$, where $G$ is a function that takes values strictly between 0 and $1(0<G(Z)<1)$, for all the real numbers of $z$, for the Logit model whose expression will be:

$$
\text { Si } G(z)=\frac{e^{z}}{1+e^{z}}
$$

Equation (2) 


$$
Y=G(z)=G\left(\beta_{0}+\beta_{1} X_{1}+\beta_{2} X_{2}+\beta_{k} X_{k}\right)=\frac{e^{\beta_{0}+\beta_{1} X_{1}+\beta_{2} X_{2}+\beta_{k} X_{k}}}{1+e^{\beta_{0}+\beta_{1} X_{1}+\beta_{2} X_{2}+\beta_{k} X_{k}}}
$$

Equation (3)

The logistic regression coefficients can be used to estimate the ratio of the advantages of probability for success to the probability of failure of each independent variable of the model. Operatively, parameters and are estimated by maximum likelihood through the model (Logit binomial).

\section{Maximum likelihood method}

The method that was used to estimate the Logit model is the Maximum Likelihood Method. This method estimates the parameters of the model maximizing the likelihood function with regard to the parameters of the model, finding the values of the parameters that maximize the probability of finding the responses obtained in the survey, according to (Pérez, 2007), the logarithm of the conditional likelihood function is given by:

$$
L(\beta)=\prod_{y i=1} P_{j} \prod_{y i=0}=(1-P j)=\prod_{i=1}^{n} G\left(X^{\prime} \beta\right)^{Y^{i}}\left(1-G\left(X^{\prime} \beta\right)\right)^{1=Y_{i}}
$$

Equation (4)

\section{RESULTS AND DISCUSSION}

\section{Descriptive analysis of the production indicators}

A descriptive analysis of the information compiled through the questionnaire applied to Persian lime producers in Martínez de la Torre was made. Graph 1 represents the variable sex, and it shows that the women are only 4 percent, which is why Persian lime production is led by men with 96 percent; it should be highlighted that women have very low participation in the Persian lime production. When it comes to the variable of age, it is observed that 37 percent of the producers are men in ages between 50 and 69 years and

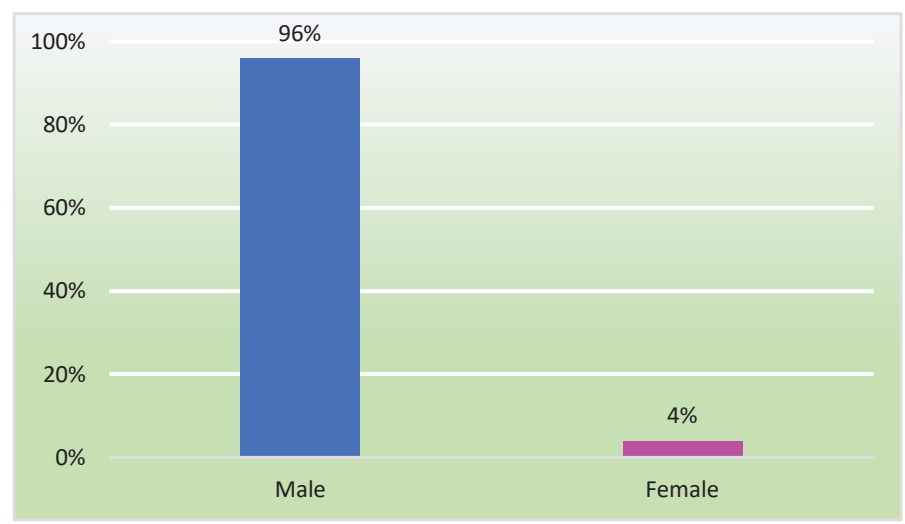

Graph 1. Sex of Persian lime producers.

Source: Prepared by authors based on field research 2020. 
only 2 percent are women in ages between 30 and 49 years. Finally, age is not limiting to Persian lime production since in the results obtained they indicate that the maximum age is 84 years and the minimum 32 years; the mean age of producers of Persian lime is 54 years (Graph 2).

Concerning the type of property, Graph 3 shows that 86 percent of Persian lime producers have ejido property; this 86 percent is made up by 42 producers, and on the other hand, only 14 percent own private property.

Graph 4 refers to the time that producers from Martínez de la Torre have been producing Persian lime, and it was observed that the class of highest predominance is between the class interval of 15 to 20 years, with this class being the one of highest percentage with 31 percent and an absolute frequency of 15 producers.

Graph 5 represents the type of knowledge that Persian lime producers apply in Martínez de la Torre, where they were qualified as: Do apply and Do not apply.

The analysis where they Do apply was the following: The producers are influenced in their totality, with 100 percent, with the class interval of rainfall since it is fundamental for

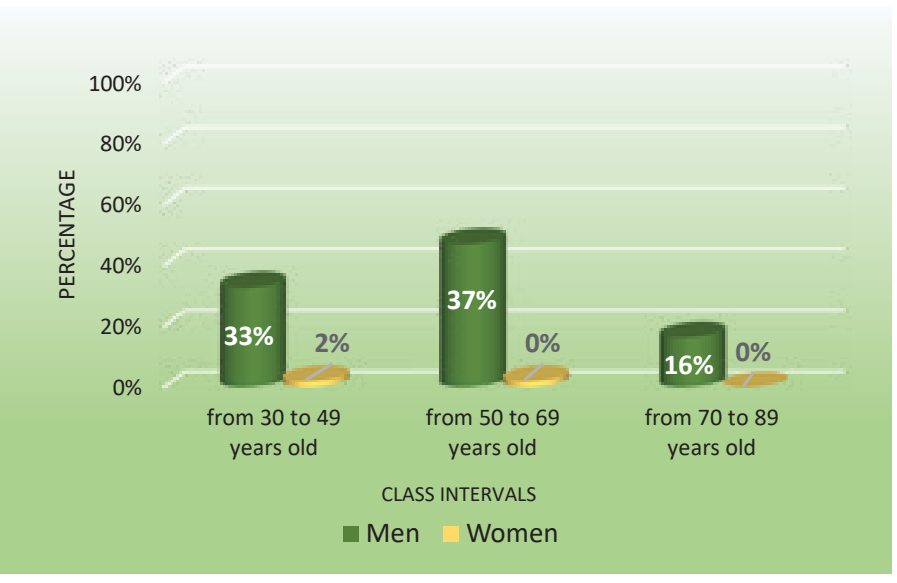

Graph 2. Age of Persian lemon producers.

Source: Prepared by authors based on field research 2020.

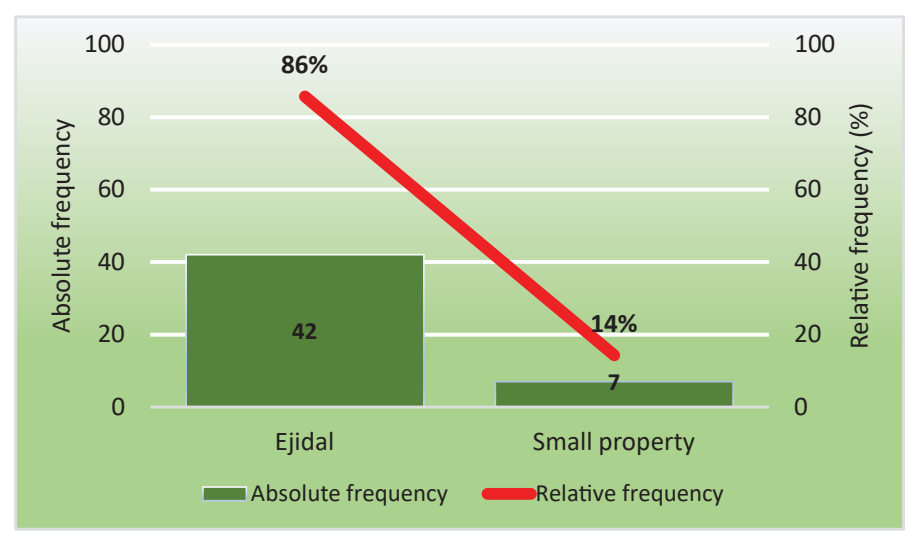

Graph 3. Type of residence property.

Source: Prepared by authors based on field research 2020. 


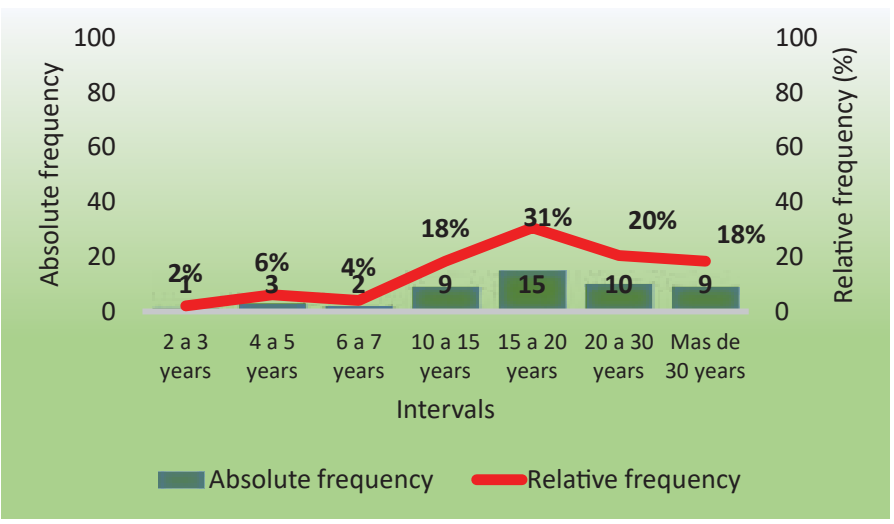

Graph 4. Years as lime producer.

Source: Prepared by authors based on field research 2020.

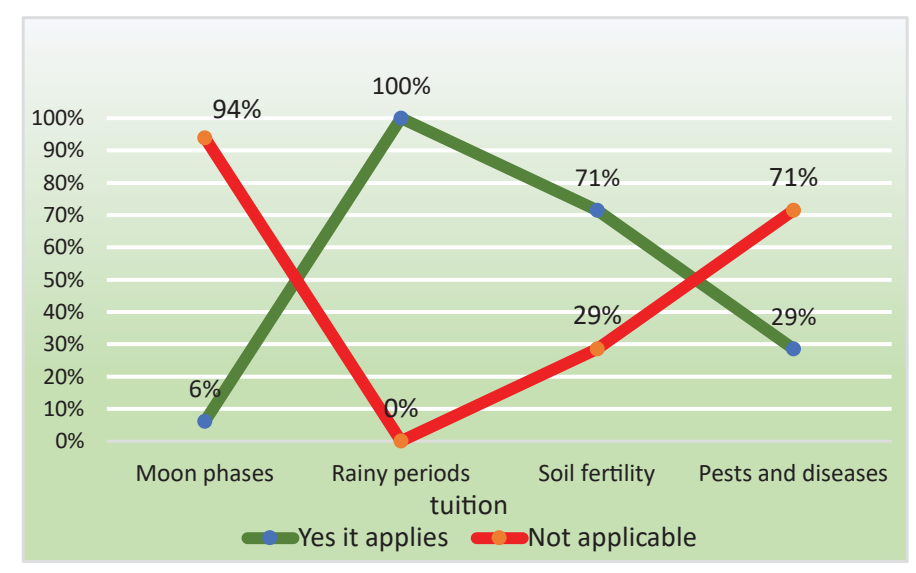

Graph 5. Type of applied knowledge.

Source: Prepared by authors based on field research 2020.

the crop's development; soil fertility is another important indicator where the producers are taken as reference for lime production and is represented by 71 percent of the total producers; for the class of pests and diseases, it represents 29 percent of the total producers; the lunar phases are applied by only 6 percent of the producers.

The analysis where they Do not apply is the following: For the class of pests and diseases, 71 percent of the total producers do not apply this knowledge, the class soil fertility is represented by 29 percent of the total producers, which pointed out that they do not apply this knowledge, and in terms of the class lunar phases, 6 percent of the total of producers do not apply this knowledge.

In relation to the pattern that they use for Persian lime shade, they are divided into two categories: tolerant and intolerant. The analysis showed the following: in Graph 6, 29 percent is represented by 14 producers who work with both patterns, it should be highlighted that the tolerant patterns most used for Persian lime production are: Swingle, Volkameriano and Macrofila, and the intolerant pattern is Cucho; 55 percent is represented by 27 producers who work with the intolerant pattern; 16 percent is represented by 8 producers, who are producing with tolerant patterns. 


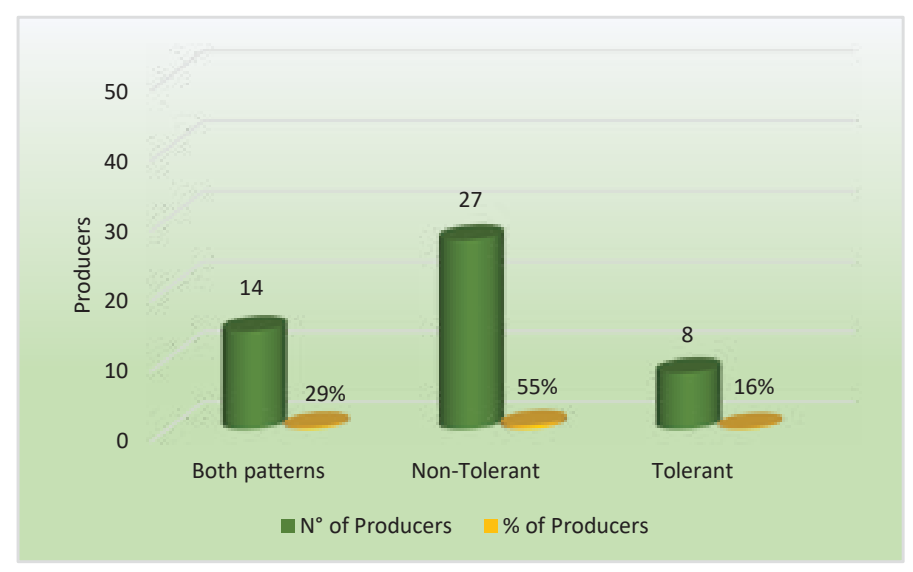

Graph 6. Type of pattern used.

Source: Prepared by authors based on field research 2020.

\section{Results from the Logit regression model}

From the econometric model of the Logit logistic distribution, the production is considered as dependent variable and as explicative independent variables: surface sown in (ha), fertilizer 20-10-20, complex fertilizer and they are declared in the following way:

$$
\begin{aligned}
\text { PRODUCTIVITY } & =\alpha_{0}+\beta_{1} \text { SURFACE }- \text { SOWN }+\beta_{2} \text { FERT }-201020 \\
& +\beta_{3} \text { FERT }- \text { COMPLEX }
\end{aligned}
$$

The Logit regression for the first step shows that 64 percent of the cases were adjusted correctly as shown in Table 2.

Another information exit obtained by the Logit regression in Table 3 was the Hosmer and Lemeshow test. Normally it is recommended that the value be higher than .05 to point out that it is a reliable model; for this case the study showed that it is higher than .05, verifying that it is a reliable and well-adjusted model with a value of .783.

On the other hand, Table 4 shows in the first column the values $\mathrm{B}(\boldsymbol{\beta})$ that represent the coefficients, highlighting that these are not read as ordinary least squares coefficients, but

\begin{tabular}{|c|c|c|c|c|c|}
\hline & \multirow{3}{*}{\multicolumn{2}{|c|}{ Observed }} & \multicolumn{3}{|c|}{ Predicted } \\
\hline & & & \multicolumn{2}{|c|}{ Productivity } & \multirow{2}{*}{ Correct percentage } \\
\hline & & & Low produces & High production & \\
\hline \multirow{3}{*}{ Step 0} & \multirow{2}{*}{ Productivity } & Low production & 0 & 18 & 0.0 \\
\hline & & High production & 0 & 32 & 100.0 \\
\hline & \multicolumn{2}{|c|}{ Overall percentage } & & & 64.0 \\
\hline
\end{tabular}

Table 2. Dependent variable leaderboard ${ }^{\mathrm{ab}}$.

a. A constant is included in the model.

b. The cut value is .500

Source: Prepared by authors with Software SPSS v.25, field research 2020. 
Table 3. Hosmer and Lemeshow test.

\begin{tabular}{c|c|c|c}
\hline Step & Ghi square & gl & Sig. \\
\hline 1 & 3.969 & 7 & .783 \\
\hline
\end{tabular}

Source: Prepared by authors with Software SPSS v.25, field research 2020.

rather they only serve to see if there is a positive or negative relation with the dependent variable. In the fifth column the Sig. values $(P$ value $)$ are found, which manifest if the independent variables are significant or not, where there should be values lower than .05 , while those variables that have a value higher than .05 ought to be eliminated from the model because they are not significant. The variables that were statistically significant are SURFACE_SOWN, FERT_201020, FERT_COMPLEX.

Regarding the values of Odds Ratio for the SPSS software, it is $\operatorname{Exp}(\mathbf{B})$, which shows that: The values that are equal to 1 mean that they Do not have any relation or association with the dependent variable; the values that are higher than 1 mean that there is a relation or association with the dependent variable. When it comes to the result of the $\operatorname{Exp}(\mathbf{B})$ values, there is that the independent variable FERT_20-10-20 has a positive ratio, with the ratio value higher than 1 , which means that an increase of a unit in the application of fertilizer 20-10-20 would increase the production; the independent SURFACE_SOWN variable also shows a positive relation higher than 1 with a ratio value of 1.36 , meaning that an increase in one unit of the plantation surface can be predicted to increase 1.36 times the production. In terms of the independent variable FERT_COMPLEX, it shows a negative relation with a ratio value of .126 which is higher than 1 and therefore its result should be interpreted through its inverse which would be $+1 / .126=7.93$, meaning that an increase of one unit of this fertilizer would cause a decrease of 7.93 times in production. On the other hand, the variable when pruning is done on the crop did not represent significance with the dependent variable.

\section{CONGLUSIONS}

Martínez de la Torre is the capital of citruses, it has great advantages such as its geographic location that allows commercialization in an efficient way, in addition to having the adequate climate and soil for the development of lime and other citruses, where its greatest characteristic is the quality of the fruit. Thus, they are arriving to more markets

Table 4. Variables in the equation.

\begin{tabular}{|c|c|c|c|c|c|c|c|}
\hline & & B & E.T. & Wald & gl & Sig. & $\operatorname{Exp}(B)$ \\
\hline \multirow{5}{*}{ Step $1^{\mathrm{a}}$} & Surface_sown & .311 & .134 & 5.370 & 1 & $.020 *$ & 1.365 \\
\hline & Fert_201020 & 3.646 & 1.253 & 8.472 & 1 & $.004 *$ & 38.321 \\
\hline & Fert_complex & -2.075 & .951 & 4.761 & 1 & $.029 *$ & .126 \\
\hline & Performs_pruning & .274 & .926 & .087 & 1 & .767 & 1.315 \\
\hline & Constant & -.903 & .878 & 1.057 & 1 & .304 & .405 \\
\hline
\end{tabular}

a. Variable (s) entered in step 1: SURFACE_SOWN, FERT_201020, FERT_COMPLEX, PERFORMS_PRUNING.

* the correlation is significant at level 0.05

Source: Prepared by authors with Software SPSS v.25, field research 2020. 
each day, and eighty percent of the production goes to the international market, mainly the United States, Europe and Japan.

Considering the results obtained from Persian lime producers in the municipality Martínez de la Torre, in synthesis most of the producers are men, with an average age of 54 years. In terms of the type of property, it is ejido, the land where they have Persian lime plantations is their own, and in most cases they have been producing lime for 15 to 30 years. Regarding the knowledge applied for Persian lime production, the producers are guided by the rainy periods and soil fertility. In relation to the type of pattern that they use, the one most used is the Cucho pattern, followed by tolerant patterns such as Swingle, Volkameriano and Macrofila.

In the analysis of production, the Logit econometric model determined that the factors that affect positively the production of Persian lime are: surface sown and fertilizer 2010-20. Regarding the fertilizer complex, this variable was significant, but with a negative relation with the dependent variable since when increasing this fertilizer in one unit, the production decreases; that is, decreasing yields are obtained, since each producer must consider the optimal dose for its cultivation. Likewise, the pruning variable does not present significance with the dependent variable, indicating indifference towards the use of this technique.

\section{REFERENGES}

H. Ayuntamiento de Martínez de la Torre. (2019). Martínez de la Torre 2018-2021. Obtenido de https://www. martinezdelatorre.gob.mx/municipio/historia/

Agroproductores. (2020). agroproductores. Obtenido de http://agroproductores.com/category/cultivos/citricos/

Instituto Nacional de Estadística y Geografía (INEGI). (20 de febrero de 2020). Obtenido de https://www.inegi. org.mx/datos/

Instituto Nacional de Estadistica y Geografía. (Noviembre de 2020). Encuesta Nacional Agropecuaria. Obtenido de https://www.inegi.org.mx/contenidos/programas/ena/2017/doc/ena2017_pres.pdf

Organización de las Naciones Unidas para la Alimentación y la Agricultura (FAO). (11 de Noviembre de 2020). Subsectores agrícolas. Obtenido de http://www.fao.org/rural-employment/agricultural-sub-sectors/es/

Pérez, C. (2007). Econometría básica Técnicas y herramientas. Pearson Educación, S.A.,Madrid.

SIAP. (11 de Noviembre de 2020). siap.gob.mx/gobmx. Obtenido de http://infosiap.siap.gob.mx/gobmx/ datosAbiertos_a.php

Vivero, J. B., \& Álvarez, R. V. (11 de Noviembre de 2020). Introducción a la agronomía. EDIMEC, 127. Obtenido de http://www.dspace.uce.edu.ec/bitstream/25000/5221/1/Introduccion\%20a\%20la\%20 agronomia.pdf 